\title{
UJI PUPUK KCL DAN BOKASI GULMA TERHADAP PRODUKSI TANAMAN JAGUNG MANIS (Zea mays saccarata Sturt)
}

\author{
KCL and Bokashi Gulma Fertilizer Experiment to Production Sweet Corn \\ (Zea mays Saccarata Sturt)
}

\author{
Zulkifli dan Putri Lukmana Sari \\ Program Studi Agraoteknologi, Fakultas Pertanian, Universitas Islam Riau \\ Jl. Kaharuddin Nasution No. 113 P. Marpoyan, Pekanbaru, Riau 28284, Indonesia. \\ Email; Ir.Zulkifli-ms@gmail.com \\ [Diterima Januari 2018; Disetujui April 2018]
}

\begin{abstract}
Corn is the most important food commodity which contains second-grade carbohydrate after rice. People's concern over agriculture and the environment in the last years has been increasing, as it hurts the environment because of the use of inorganic materials to increase agricultural production. To minimize the negative impact, organic farming is natural agriculture that can reduce the use of inorganic materials. Bokashi is a fermented organic fertilizer with EM4 technology (Effective Microorganisms-4). KCL fertilizer is an organic fertilizer to play a role in strengthening the plant so as not to be easily broken. The objective of this research is to make the experiment with the effect of giving KCL and weed bokashi interaction and single to the production of sweet corn. This study used Completely Randomized Design (RAL), Factorial 4x4 with treatment as a Dose of KCL consisting of 4 levels; K0. Without the Giving of KCL, K1 KCL 20 g/plot, K2 KCL 40 g/ plot, K3 KCL 60 g/plot and Dose weed bokashi consisted of 4 levels; B0 Without the giving of weed bokashi, B1 weed bokashi $480 \mathrm{~g} / \mathrm{plot}$, B2 weed bokashi 960g/plot, B3 weed bokashi 1.440g/plot. Parameters observed include; cob length, convoluted cob and weight cob of sweet corn. The results of this study showed that KCL and weed bokashi fertilizer experiment to production sweet corn interaction had an effect on cob length, convoluted cob and weight cob of sweet corn, which doses of $\mathrm{KCl}$ will reduce the application of fertilizer Bokashi and vice versa, and KCL. Weed bokashi were balanced to maximize the production of sweet corn that is present in KCL $60 \mathrm{~g} / \mathrm{plot}$ and Bokash weed bokashi $480 \mathrm{~g} / \mathrm{plot}$ and KCL $20 \mathrm{~g} /$ plot and weed bokashi $960 \mathrm{~g} /$ plot with cob length $30,00 \mathrm{~cm}$, convoluted cob $20,17 \mathrm{~cm}$ and weight cob 465,00 g per cob.
\end{abstract}

Keywords: KCL, Weed Bokashi and Sweet Corn

\begin{abstract}
ABSTRAK
Tanaman Jagung merupakan komoditi pangan terpenting yang mengandung karbohidrat prangkat ke-2 setelah padi. Perhatian masyarakat terhadap soal pertanian dan lingkungan beberapa tahun terakhir ini menjadi meningkat, karena dirasakan dampak negatif bagi lingkungan akibat penggunaan bahan an organik dalam peningkatan produksi pertanian. Untuk menekan dampak negatif tersebut, pertanian organik merupakan pertanian alami yang mampu mengurangi penggunaan bahan anorganik. Pupuk bokasi adalah pupuk organik hasil fermentasi dengan teknologi EM4 (Effective Microorganims-4). Pupuk KCL adalah pupuk an organik berperan dalam memperkuat tanaman agar tidak mudah patah. Penelitian ini bertujuan untuk menguji pengaruh pemberian Pupuk KCL dan Bokasi Gulma secara interaksi dan tunggal terhadap produksi tanaman jagung manis. Penelitian ini menggunakan Rancangan Acak Lengkap (RAL), Faktorial $4 \mathrm{x} 4$ dengan perlakuan sebagai berikut; Dosis pemberian KCL yang terdiri dari 4 level yakni; K0 Tanpa Pemberian KCL, K1 KCL 20 g/plot, K2 KCL 40 g/plot, K3 KCL 60 g/plot dan Dosis Bokasi Gulma terdiri dari B0. Tanpa Pemberian Bokasi Gulma, B1. Bokasi Gulma 480 g/plot, B2. Bokasi Gulma 960 g/plot, B3. Bokasi Gulma 1.440 g/plot. Parameter yang diamati; Panjang tongkol, Lilit tongkol dan berat
\end{abstract}


tongkol per tongkol. Dari hasil penelitian disimpulkan bahwa uji dosis $\mathrm{KCl}$ dan bokasi gulma secara interaksi berpengaruh terhadap Panjang, lilit dan berat tongkol ,dimana dosis $\mathrm{KCl}$ yang tepat akan mengurangi pemberian pupuk Bokasi dan begitu pula sebaliknya serta pupuk KCL dan Bokasi yang seimbang akan dapat memaksimalkan produksi tanaman jagung manis yakni terdapat pada dosis pemberian $\mathrm{KCl} 60$ gram,Bokasi 480 gram dan Dosis $\mathrm{KCl} 20$ gram, Bokasi 960 gram yakni $\mathrm{KCl} 20$ gram per plot dengan produksi Panjang tongkol 30,00 cm, lilit tongkol 20,17 $\mathrm{cm}$ dan berat tongkol 465,00 gram per tongkol.

\section{Kata Kunci: KCL, Bokashi Gulma and Jagung Manis}

\section{PENDAHULUAN}

Tanaman jagung di Indonesia merupakan komoditi pangan terpenting yang mengandung karbohidrat setelah padi. Produksi jagung manis bila dilihat secara nasional terdapat kecendurungan dari tahun -ke tahun terjadi penurunan produksi (Marzuki, 2002).

Rukmana dalam_Mustari (2004) tanaman jagung banyak diusahakan karena komoditas ini secara ekonomis sangat menguntungkan untuk dijadikan pangan pengganti beras atau dicampur dengan beras karena kandungan gizinya lebih tinggi dari beras.

Perhatian masyarakat terhadap soal pertanian dan lingkungan beberapa tahun terakhir ini menjadi meningkat. Karena semakin dirasakannya dampak negatif yang besar bagi lingkungan akibat pemakaian bahan anorganik (Pupuk KCl). Untuk menekan dampak negatif tersebut dalam usaha pertanian harus mengurangi penggunaan bahan anorganik dalam peningkatan produksi. Pupuk $\mathrm{KCl}$ merupakan pupuk an organik yang dibutuhkan oleh tanaman dalam jumlah yangbesar sehingga dalam pemberiannya dibutuhkan jumlah yang banyak.

Kalium klorida $(\mathrm{KCl})$ merupakan salah satu jenis pupuk kalium, dengan kandungan unsure haradalam pupuk ini adalah $60 \% \mathrm{~K} 2 \mathrm{O}$, pemberian kalium ke dalam tanah dapat menambah jumlah kalium tersedia, kalium penting dalam memacu pertumbuhan dan memperlancar terjadinya fotosintesis (Anonim, 1989) dalam Bunyamin (2017) Lingga dan Marsono (2006) bahwa fungsi utama kalium (K) ialah membantu pembentukan protein dan karbohidrat.Kalium pun berperan dalam memperkuat tubuh tanaman.

Bunyamin (2017) menyatakan bahwa unsure kalium yang terdapat di tanah secara alami akan tercuci oleh air hujan sehingga sedikit tersedia bagi tanaman. Tanaman yang kekurangan unsure kalium akan terhambat pertumbuhan maupun kualitas hasil akan proses asimilasi karbon akan terhenti.

Tanaman jagung manis memerlukan kalium dalam jumlah yang tinggi yaitu berkisar antara $50-300 \mathrm{~kg} \mathrm{~K}$ per ha permusim tanam( Laegreid dkk, 1999) dalam Bunyamin (2017). Hal ini menunjukan bahwa kebutuhan $\mathrm{K}$ oleh tanaman jagung manis cukup tinggi dan apabila kebutuhan tersebut tidak terpenuhi maka proses metabolisme tanaman terganggu sehingga produktivitas tanaman dan mutu hasil menjadi rendah.

Berdasarkan penelitian bahwa pemupukan kalium memberikan respon yang baik pada pertumbuhan dan hasil jagung manis. Rasa manis pada jagung manis diduga dipengaruhi oleh adanya unsure hara K. Kalium diserap dalam bentuk ion $\mathrm{K}^{+}$. Namun penggunaan Pupuk $\mathrm{KCl}$ dapat dikurangi melalui penggunaan Pupuk Organik. Pertanian organik merupakan bagian dari pertanian alami yang dalam memperbaiki kesuburan tanah. Sering menggunakan bahan alami (pupuk organik) seperti mendaur ulang limbah pertanian, dengan mengubah limbah tersebut menjadi pupuk organik diantaranya pupuk Bokasi.

Bokashi adalah bahan alami atau limbah pertanian yang didaur ulang, yang selama ini hanya terbatas pada limbah.Bokasi bila dilihat dari bahan pokok yang digunakan dalam pembuatan pupuk tersebut ada kesamaan dengan pupuk kompos. Hanya dari proses pembuatannya berbeda, dimana pupuk kompos proses pembuatannya melalui pengomposan tidak menggunakan EM4 sedangkan bokasimelalui proses fermentasi atau peragian bahan limbah alami dengan teknologi EM4 (Effective Microorganisme 4). Oleh karena itu keunggulan penggunaan teknologi EM4 adalah pupuk bokasi dapat dihasilkan dalam waktu yang relatif singkat.Dari sisi lain EM4 sendiri mengandung Azotobacter sp, Lactobacillus sp, 
ragi, bakteri fotosintetik, 4 mikrobiaini merupakan jamur pengurai selulosa, sehingga selulosa yang terkandung dalam limbah atau bahan alami tersebut akan lebih cepat terurai menjadi bahan yang berguna bagi tanaman berupa hara.

Kadekoh dan Amirudin (2007) mengatakan bahwa bahan organic bersifat multi fungsi yaitu mampu memperbaiki sifat fisik, kimia dan biologi tanah. Sumarsono dkk (2005) dalam Bunyamin (2017), menyatakan bahwa tanaman yang diberi pupuk organic akan mampu memperbaiki kandungan C-organik tanah menjadi 4,5\% lebih tinggi dibandingkan tanpa pupuk. Admin (2004), mengatakan bahwa pupuk organicmengandung unsure hara nitrogen $(\mathrm{N})$, phosphor $(\mathrm{P})$, dan kalium $(\mathrm{K})$ yang rendah, tetapi mengandung hara mikro yang berlimpah serta diperlukan untuk pertumbuhan tanaman. Hermansyah, (2013) mengatakan bahwa pemberian pupuk organik (kotoran sapi, kambing dan ayam) dapat mendukung pertumbuhan Azotobacteri pada tanaman. Soplanit dan Soplanit (2012), mengatakan bahwa Pemberian bokasi sagu yang dikombinasikan pemberian pupuk SP-36 mampu meningkatkan serapan $\mathrm{P}$, tinggi tanaman dan diameter batang jagung. EM-4 yang digunakan dalam pembuatan bokasi adalah suatu kultur campuran berbagai mikroorganisme yang bermanfaat (terutama bakteri fotosintetik dan bakteri asam laktat, ragi, actinomycetes, dan jamur peragian) dan dapat digunakan sebagai inokulan untuk meningkatkan keragaman mikroba tanah. Sutanto (2002) mengatakan bahwa EM4 menguntungkan terhadap pembentukan buah dan kematangan hasil tanaman. Ruhukail (2011) mengatakan bahwa adanya pengaruh signifikan pemberian EM4 terhadap pertumbuhan dan produksi tanaman. Raihana dkk (2009) mengatakan bahwa kompos dengan stimulasi EM4 dapat meningkatkan pertumbuhan dan produksi tanaman jagung manis. Mustari (2004) menyimpulkan bahwa pemberian pupuk bokasi dapat meningkatkan kadar hara tanah dan memperbaiki $\mathrm{pH}$ tanah.

Pemberian pupuk bokasi dapat meningkatkan produksi dan produktivitas tanaman jagung. Hasil penelitian Kadekoh dan Amirudin (2007) menunjukkan bahwa pemberian bokasi meberikan hasil terbaik pada panjang tongkol dan diameter tongkol dibandingkan tanpa bokasi. Yuliana dkk (2013), mengatakan bahwa pengunaan bokasi sebanyak 15 ton mampu meningkatkan hasil tanaman jagung sebesar 23,86 \% dibandingkan tanpa pemberian pupuk bokasi. Lingga dan Marsono (2006), mengatakan bahwa pemberian bokasi memiliki kelebihan yaitu memperbaiki struktur tanah, meningkatkan daya serap tanah terhadap air, menaikkan kondisi kehidupan mikroorganisme di dalam tanah dan sebagai sumber hara bagi tanaman.Respon tanaman jagung manis terhadap dosis dan jenis pupuk organik secara interaksi memberikan pengaruh yang significan, dimana salah satu jenis pupuk organik yang dipakai adalah pupuk bokasi dari hasil penelitian disimpulkannya perlakuan terbaik yakni pemberian bokasi 400 gram per plot dengan hasil diameter tongkol $1,8 \mathrm{~cm}$, luas daun $6354,14 \mathrm{~cm}$ dan panjang tongkol tanpa kelobot 20,73 cm (Zulkifli dan Herman, 2012). Zulkifli dan Lukmanasari (2014) bahwa jenis bokasi terbaik adalah bokasi gulma dengan dosis pemberian 10 gram per tanaman dengan panjang tongkol $13,70 \mathrm{~cm}$, diameter tongkol $4,10 \mathrm{~cm}$ dan berat tongkol 95 gram per tongkol.

\section{METODE PENELITIAN.}

Penelitian ini menggunakan Rancangan Acak Lengkap ( RAL ), Faktorial 4 x 4 dengan perlakuan sebagai berikut : Faktor pertama Dosis pemberian KCL yang terdiri dari 4 level yakni; K0 (Tanpa Pemberian KCL), K1 (KCL 20 g/plot), K2 (KCL 40 g/plot), K3 (KCL 60 g/plot) dan Faktor kedua Dosis Bokasi Gulma terdiri dari B0 (Tanpa Pemberian Bokasi Gulma), B1(Bokasi Gulma 480 g/plot), B2 (Bokasi Gulma 960 g/plot), B3 (Bokasi Gulma $1.440 \mathrm{~g} /$ plot)dengan demikian terdapat 16 kombinasi perlakuan yang masing - masingnya di ulang sebanyak 3 kali dan setiap plot percobaan terdiri dari 4 bedengan yang berisikan 16 tanaman dan 2 tanaman dijadikan sampel.

Penelitian ini dilaksanakan di Kebun Percobaan Fakultas Pertanian UIR. Jl. Kaharudin Nasution No 113 Kel. Air Dingin Kec. Bukit Raya, Kota Pekanbaru. Penelitian dilaksanakan Februari sampai Mei 2017.

Bahan yang digunakan dalam penelitian ini benih Jagung Manis UnggulMulia, Pupuk KCL,Pupuk Bokasi Gulma dan NPK Mutiara (16:16:16), tali rafiya, Seng Plat, kertas. Alat 
yang dipergunakan antara lain cangkul, parang, pisau cutter, oven listrik, sketmack,meteran, timbangan analitik, gembor, kamera, seperangkat alat analisis dan alat tulis lainnya.

Data hasil pengamatan di analisa dengan menggunakan sidik ragam dan uji lanjut BNJ pada taraf $5 \%$.

\section{HASIL DAN PEMBAHASAN}

\section{Panjang Tongkol}

Hasil penelitian menunjukkan bahwa Uji Pupuk $\mathrm{KCl}$ dan Bokasi Gulma secara interaksi berpengaruh nyata terhadap Panjang Tongkol Jagungsebagaimana ditampilkan pada Tabel 1.

Dari Tabel 1 terlihat bahwa Panjang Tongkol terpanjang pada perlakuan K2B0, berbeda dengan K3B0, K3B3 dan tidak berbeda nyata dengan lainnya. Perbedaan ini terjadi dikarenakan adanya pengaruh dari pupuk $\mathrm{KCl}$ dan Bokasi Gulma yang di ujikan pada produksi tanaman jagung manis ini dapat dilihat adanya perbedaan panjang tongkol yang dihasilkan oleh tanaman tersebut, perbedaan ini disebabkan adanya perbedaan jumlah hara yang terdapat pada pupuk $\mathrm{KCl}$ dan Bokasi Gulma yang diserap oleh tanaman sehingga menyebabkan terjadi perbedaan panjang tongkol. Sebagaimana yang dikemukakan oleh Lingga dan Marsono (2006) bahwa fungsi utama kalium (K) ialah membantu pembentukan protein dan karbohidrat. Kalium pun berperan dalam memperkuat tubuh tanaman.

Tabel 1Uji Dosis pupuk KCl dan Bokasi Terhadap Panjang Tongkol Tanaman Jagung(cm).

\begin{tabular}{ccccc}
\hline Perlakuan & B0 & B1 & B2 & B3 \\
\hline K0 & $29,33 \mathrm{ab}$ & $26,67 \mathrm{ab}$ & $27,00 \mathrm{ab}$ & $30,00 \mathrm{ab}$ \\
K1 & $30,17 \mathrm{ab}$ & $28,83 \mathrm{ab}$ & $30,00 \mathrm{ab}$ & $29,33 \mathrm{ab}$ \\
K2 & $31,00 \mathrm{a}$ & $29,33 \mathrm{ab}$ & $28,00 \mathrm{ab}$ & $27,67 \mathrm{ab}$ \\
K3 & $26,5 \mathrm{~b}$ & $28,33 \mathrm{ab}$ & $29,50 \mathrm{ab}$ & $19,00 \mathrm{c}$ \\
\hline KK $=5,22 \%$ & & & &
\end{tabular}

Angka-angka yang diikuti oleh huruf yang sama pada tiap baris dan kolam tidak berbeda nyata menurut uji BNJ pada taraf nyata $5 \%$.

Bunyamin (2017) menyatakan bahwa unsure kalium yang terdapat di tanah secara alami akan tercuci oleh air hujan sehinggasedikit tersedia bagi tanaman. Tanaman yang kekurangan unsur kalium akan terhambat pertumbuhan maupun kualitas hasil akan proses asimilasi karbon akan terhenti. Hal ini menunjukan bahwa kebutuhan $\mathrm{K}$ oleh tanaman jagung manis cukup tinggi dan apabila kebutuhan tersebut tidak terpenuhi maka proses metoblisme tanaman terganggu sehingga produktivitas tanaman dan mutu hasil menjadi rendah.

Berdasarkan penelitian bahwa pemupukan kalium memberikan respon yang baik padapertumbuhan dan hasil jagung manis. Rasa manis pada jagung manis diduga dipengaruhi oleh adanya unsur hara $\mathrm{K}$. Sutanto (2002) mengatakan bahwa EM4 menguntungkan terhadap pembentukan buah dan kematangan hasil tanaman.Yulhasmir (2009) mengatakan bahwa pemberian

EM4 memberikan pengaruh baik terhadap produksi tanaman jagung. Ruhukail (2011) mengatakan bahwa adanya pengaruh siknifikan pemberian EM4 terhadap produksi tanaman. Arpani dalam Mustari, (2004) menyatakan bahwa pupuk bokasi, mampu meningkatkan produksi dan produktivitas tanaman jagung manis.Mustari(2004), menyimpulkan bahwa pemberian pupuk bokasi dapat meningkatkan kadar hara tanah dan memperbaiki $\mathrm{pH}$ tanah. Pemberian pupuk bokasi dapat meningkatkan produksi dan produktivitas tanaman jagung.Lingga dan Marsono (2001), mengatakan bahwa pemberian bokasi memiliki kelebihan yaitu memperbaiki struktur tanah, meningkatkan daya serap tanah terhadap air, menaikkan kondisi kehidupan mikroorganisme di dalam tanah dan sebagai sumber hara bagi tanaman. Agustina (2004) mengatakan bahwa pemberian kompos 30 ton per hektar berpengaruh baik terhadap sifat fisik tanah yakni menurunkan berat isi tanah, berat jenis dan pori drenase cepat serta memperbaiki pertumbuhan tanaman jagung. 


\section{Lilit Tongkol (cm)}

Hasil penelitian menunjukkan bahwa Uji Pupuk $\mathrm{KCl}$ dan Bokasi Gulma secara interaksi berpengaruh nyata terhadap Lilit Tongkol sebagaimana ditampilkan pada Tabel 2. Dari Tabel 2 terlihat bahwa Lilit Tongkol terbesar pada perlakuan $\mathrm{K} 2 \mathrm{~B} 0$, berbeda dengan $\mathrm{K} 3 \mathrm{~B} 0$, K3B3, K2B2, K0B0, K0B1, K0B2 dan tidak berbeda nyata dengan lainnya. Perbedaan ini terjadi dikarenakan adanya pengaruh dari pupuk $\mathrm{KCl}$ dan Bokasi Gulma yang di ujikan pada produksi ini terdilihat pada indikator lilit tongkol yang dihasilkan oleh tanaman tersebut, perbedaan ini disebabkan adanya perbedaan hara yang diserap dari pupuk $\mathrm{KCl}$ dan Bokasi Gulma yang diujikan pada tanaman sehingga menyebabkan terjadi perbedaan lilit tongkol. Sebagaimana yang dikemukakan oleh Lingga dan Marsono (2006) bahwa fungsi utama kalium (K) ialah membantu pembentukan protein dan karbohidrat. Kalium pun berperan dalam memperkuat tubuh tanaman.

Tabel 2. Uji Dosis pupuk KCl dan Bokasi Terhadap Lilit Tongkol Tanaman Jagung(cm).

\begin{tabular}{ccccc}
\hline Perlakuan & B0 & B1 & B2 & B3 \\
\hline K0 & $18,67 \mathrm{c}$ & $18,32 \mathrm{c}$ & $18,17 \mathrm{c}$ & $19,25 \mathrm{abc}$ \\
K1 & $18,92 \mathrm{bc}$ & $19,83 \mathrm{abc}$ & $19,83 \mathrm{abc}$ & $19,58 \mathrm{abc}$ \\
K2 & $20,50 \mathrm{a}$ & $19,33 \mathrm{abc}$ & $18,67 \mathrm{c}$ & $20,50 \mathrm{a}$ \\
$\mathrm{K} 3$ & $19,00 \mathrm{bc}$ & $20,17 \mathrm{ab}$ & $19,33 \mathrm{abc}$ & $19,00 \mathrm{c}$ \\
\hline
\end{tabular}

$\mathrm{KK}=2,31 \% \mathrm{BNJ} \mathrm{KB}=1,37$

Angka-angka yang diikuti oleh huruf yang sama pada tiap baris dan kolam tidak berbeda nyata menurut uji BNJ pada taraf nyata $5 \%$.

Bunyamin (2017) menyatakan bahwa unsure kaliumyangterdapat di tanah secaraalami akan tercuci oleh airhujan sehinggasedikit tersediabagi tanaman. Tanaman yang kekurangan unsur kalium akan terhambat pertumbuhan maupun kualitas hasil akan proses asimilasi karbon akan terhenti. Halini menunjukkan bahwa kebutuhan K oleh tanaman jagung manis cukup tinggi dan apabila kebutuhan tersebut tidak terpenuhi maka proses metoblisme tanaman terganggu sehingga produktivitas tanaman dan mutu hasil menjadi rendah.

Berdasarkan hasil penelitian bahwa pemupukan kalium memberikan respon yang baik pada pertumbuhan dan hasil jagung manis. Rasa manis pada jagung manis diduga dipengaruhi oleh adanya unsur hara K. Bokasi adalah pupuk oganik yang berasal dari bahan organik yang telah mengalami fermentasi dimana sebagai mikro organisme berasal dari EM4 yang ditambahkan dalam proses pembuatan bokasi tersebut. Maka bokasi punya fungsi ganda, sehingga akan mampu memperbaiki tanah yang akan dipakai sebagai media tempat tumbuhnya tanaman khususnya jagung manis yang dipakai sebagai objek dalam penelitian ini. Kadekoh dan Amirudin (2007) mengatakan bahwa bahan organik bersifat multi fungsi yaitu mampu memperbaiki sifat fisik, kimia dan biologi tanah. Sumarsono dkk (2005) dalam Bunyamin (2017) menyatakan bahwa tanaman yang diberi pupuk organic akan mampu memperbaiki kandungan $\mathrm{C}$-organik tanah menjadi $4,5 \%$ lebih tinggi dibandingkan tanpa pupuk. Admin (2004) mengatakan bahwa pupuk organik mengandung unsur hara nitrogen $(\mathrm{N})$, phosphor $(\mathrm{P})$, dan kalium $(\mathrm{K})$ yang rendah serta hara mikroyang berlimpah serta diperlukan untuk pertumbuhan tanaman. Zulkarnain dan Prasetio (2013) mengatakan bahwa pemberian pupuk organik disamping meningkatkan bahan organik dan sifat fisik tanah juga berpengaruh terhadap produksi tanaman sebesar $94,7 \%$.

Pupuk Bokasilah satu bentuk pupuk organik dibuat dengan memfermentasikan bahan-bahan organik (dedak, ampas kelapa, tepung ikan, dsb) dengan EM (Efektive Microorganism).Widiana dalam Mustari,(2004) menyebutkan bahwa limbah tanaman dapat dijadikan pupuk bokasi dengan cara mencampurkan limbah tersebut dengan Efektif Mikroorganisms-4 (EM4), dedak, sekam dan pupuk kandang. EM yang digunakan dalam pembuatan bokashi adalah suatu kultur campuran berbagai mikrorganisme yang bermanfaat (terutama bakteri fotosintetik dan bakteri asam laktat, ragi, actinomycetes, dan jamur peragian) dan dapat digunakan sebagai inokulan untuk meningkatkan keragaman mikroba tanah. Sutanto (2002) mengatakan bahwa EM4 menguntungkan terhadap 
pembentukan buah dan kematangan produksi tanaman.Yulhasmir (2009) mengatakan bahwa pemberian EM4memberikan pengaruh baik terhadapproduksi tanaman jagung. Ruhukail (2011) mengatakan bahwa adanya pengaruh siknifikan pemberian EM4 terhadap produksi tanaman. Raihana dkk (2009) mengatakan bahwa kompos dengan stimulasi EM4 dapat meningkatkan produksi tanaman jagung. Arpani dalam Mustari (2004) menyatakan bahwa pupuk bokasi mampu meningkatkan produksi dan produktivitas tanaman jagung manis. Mustari (2004) menyimpulkan bahwa pemberian pupuk bokasi dapat meningkatkan kadar hara tanah dan memperbaiki $\mathrm{pH}$ tanah. Lingga dan Marsono (2006) mengatakan bahwa pemberian bokasi memiliki kelebihan yaitu memperbaiki struktur tanah, meningkatkan daya serap tanah terhadap air, menaikkan kondisi kehidupan mikroorganisme di dalam tanah dan sebagai sumber hara bagi tanaman.

\section{Berat Tongkol (gram)}

Hasil penelitian menunjukkan bahwa Uji Pupuk $\mathrm{KCl}$ dan Bokasi Gulma secara interaksi berpengaruh nyata terhadap Berat Tongkol sebagaimana ditampilkan pada tabel 3.Dari tabel 3 terlihat bahwa Berat Tongkol terberat pada perlakuan K0B3 tidak berbeda dengan $\mathrm{K} 1 \mathrm{~B} 2$, K2B0, K3B1 dan berbeda nyata dengan lainnya.

Tabel 3. Uji Dosis pupuk KCl dan Bokasi Terhadap Berat Tongkol Tanaman Jagung(gram).

\begin{tabular}{ccclc}
\hline Perlakuan & B0 & B1 & B2 & B3 \\
\hline K0 & $395,00 \mathrm{c}$ & $379,33 \mathrm{c}$ & $395,00 \mathrm{c}$ & $460,00 \mathrm{a}$ \\
K1 & $371,67 \mathrm{c}$ & $395,00 \mathrm{c}$ & $431,67 \mathrm{abc}$ & $401,67 \mathrm{c}$ \\
K2 & $451,67 \mathrm{ab}$ & $403,33 \mathrm{c}$ & $366,67 \mathrm{c}$ & $415,00 \mathrm{bc}$ \\
K3 & $388,33 \mathrm{c}$ & $465,00 \mathrm{a}$ & $350,00 \mathrm{c}$ & $411,67 \mathrm{bc}$ \\
\hline KK $=3,36 \%$ BNJ BK $=41,24$ & & &
\end{tabular}

Angka-angka yang diikuti oleh huruf yang sama pada tiap baris dan kolam tidak berbeda nyata menurut uji BNJ pada taraf nyata $5 \%$.

Perbedaan ini terjadi dikarenakan adanya pengaruh dari pupuk $\mathrm{KCl}$ dan Bokasi Gulma yang di ujikan pada produksi tanaman jagung manis ini dapat dilihat adanya perbedaan berat tongkol yang dihasilkan oleh tanaman tersebut, perbedaan ini disebabkan adanya perbedaan jumlah hara yang terdapat pada pupuk $\mathrm{KCl}$ dan Bokasi Gulma yang diserap oleh tanaman sehingga menyebabkan terjadi perbedaan berat tongkol. Sebagaimana yang dikemukakan oleh Lingga dan Marsono (2006) bahwa fungsi utama kalium (K) ialah membantu pembentukan protein dan karbohidrat. Kalium pun berperan dalam memperkuat tubuh tanaman.

Bunyamin (2017) menyatakan bahwa unsure kalium yang terdapat di tanah secara alami akan tercuci oleh air hujan sehingga sedikit tersedia bagi tanaman. Tanaman yang kekurangan unsur kalium akan terhambat pertumbuhan maupun kualitas hasil akan proses asimilasi karbon akan terhenti.

Berdasarkan hasil penelitian bahwa pemupukan kalium memberikan respon yang baik pada pertumbuhan dan hasil jagung manis. Rasa manis pada jagung manis diduga dipengaruhi oleh adanya unsur hara K. Sutanto
(2002) mengatakan bahwa EM4 menguntungkan terhadap pembentukan buah dan kematangan hasil tanaman Yulhasmir (2009) mengatakan bahwa pemberian EM4 memberikan pengaruh baik terhadap produksi tanaman jagung. Ruhukail (2011) mengatakan bahwa adanya pengaruh siknifikan pemberian EM4 terhadapproduksi tanaman. Arpani dalam Mustari (2004) menyatakan bahwa pupuk bokasi mampu meningkatkan produksi dan produktivitas tanaman jagung manis. Mustari (2004) menyimpulkan bahwa pemberian pupuk bokasi dapat meningkatkan kadar hara tanah dan memperbaiki $\mathrm{pH}$ tanah. Pemberian pupuk bokasi dapat meningkatkan produksi dan produktivitas tanaman jagung.Lingga dan Marsono (2006) mengatakan bahwa pemberian bokasi memiliki kelebihan yaitu memperbaiki struktur tanah, meningkatkan daya serap tanah terhadap air, menaikkan kondisi kehidupan mikroorganisme di dalam tanah dan sebagai sumber hara bagi tanaman. 


\section{KESIMPULAN}

Hasil penelitian disimpulkan bahwa uji dosis $\mathrm{KCl}$ dan bokasi gulma secara interaksi berpengaruh terhadap Panjang, lilit dan berat tongkol. Dimana dosis $\mathrm{KCl}$ yang tepat akan mengurangi pemberian pupuk Bokasi dan begitu pula sebaliknya serta pupuk KCL dapat menggantikan Pupuk Bokasi dan sebaliknya.

Hasil terbaik pada interaksi pemberian $\mathrm{KCl} 60$ gram dan Bokasi 480 gram; $\mathrm{KCl} 20$ gram dan Bokasi 960 gram dengan Panjang tongkol $30,00 \mathrm{~cm}$, lilit tongkol $20,17 \mathrm{~cm}$ dan berat tongkol 465,00 gram per tongkol.

\section{DAFTAR PUSTAKA}

Admin. 2004. Pupuk Bokasi dan Faktor-Faktor yang Berpengaruh Dalam Pengoposan. Balai Besar Pelatihan Pertanian, Kalimatan Selatan.

Agustina, C. 2004. Pengaruh Pemberian Kompos terhadap Beberapa Sifat Fisik Entisol serta Pertumbuhan Tanaman Jagung (Zea mays L). Skripsi. Fakultas Pertanian Brawijaya,Malang.

Bunyamin, R. 2017. Pengaruh Kompos Jerami Padi yang Diperkaya dan Pemupukan Kalium terhadap Pertumbuhan dan Produksi Tanaman Jagung Manis (Zea mays Saccharata Stur: Skripsi Jurusan Agroteknologi. Fakultas Pertanian. Universitas Lampung, Bandar Lampung.

Hermansyah, A. 2013. Pengaruh Pemberian Pupuk Kandang (Kotoran Sapi, Kambing dan Ayam) terhadap Kemelimpahan Azotobacteri $s p$ dan Pertumbuhan Kacang Tanah (Arachis hygae L). Skripsi Fakultas Sains dan Teknologi Universitas Islam Negeri Sunan Kalijaga,Yogyakarta.

Kadekoh, I dan Amirudin. 2007. Pertumbuhan Dan Hasil Jagung Pulut (Zea mays Certain) pada Bebagai Dosis Bokasi Gamal dan Pupuk NPK dalam System Alley Cropping. Jurnal Agrisains, 8(1) $: 10-17$.

Lingga dan Marsono. 2006. Petunjuk Penggunaan Pupuk. Penebar Swadaya. Jakarta.

Marzuki, R, 2002. Bertanam Jagung Manis. Penebar Swadaya. Jakarta.
Mustari, K. 2004. Penggunaan Pupuk Bokasi Pada Tanaman Jagung dalam Rangka Mengembangkan Usahatani Ramah Lingkungan. Jurnal Agrivigor, 4(1): 7481.

Nur, M. APLIKASI KEPEKATAN LARUTAN NUTRISI DAN PERSENTASE MEDIA CAMPURAN COCOPEAT-BOKASHI PADA PERTUMBUHAN DAN PRODUKSI BUTTER HEAD LETTUCE (Lactuca sativa Var Capitata L.) SECARA HIDROPONIK SYSTEM NFT.

Nur, M., Jumin, H.B. and Maizar, M., 2016. PERTUMBUHAN TANAMAN CEPLUKAN (Physalis angulata L.) PADA TANAH TERCEMAR LIMBAH BLEACHING EARTH DENGAN REMEDIASI PUPUK KANDANG. DINAMIKA PERTANIAN, 32(1), pp.35-50.

Soplanit, M dan R. Soplanit. 2012. Pengaruh Bokasi Sagu pada Berbagai Tingkat Kematangan dan Pupu SP-36 terhadap Serapan P dan Pertumbuhan Jagung pada Tanah Ultisol. Jurnal Agrologia, 1 (1): $1-10$

Sutanto. 2002. Penerapan Pertanian Organik. Kanasius.Yogyakarta.

Yurhasmir. 2009. Kosentrasi EM4 dan Jarak Tanam terhadap Pertumbuhan dan Produksi Tanaman Jagung dengan Sistem Tanpa Olah Tanah. Jurnal Agronobis, 1 (1): 1-11

Yuliana, AI. T. Sumarni dan S Fajriani, 2013. Upaya Meningkatkan Hasil Tanaman Jagung (Zea may L) dengan Pemupukan Bokasi dan Crotalaria juncea L. Jurnal Produksi Tanaman, 1 (1): 37-46

Zulkifli dan Herman. 2012. Respon Jagung Manis (Zea mays Saccharata Stut), terhadap Dosis dan Jenis Pupuk Organik. Jurnal Agroteknologi, 2 (2): 25-28.

Zulkifli dan Putri Lukmanasari. 2014. Respon Tanaman Jagung Manis (Zea mays Saccarata Sturt) Terhadap Jenis dan Dosis Pemberian Bokasi dalam Polybag. Lembaga Penelitian (LP) Universitas Islam Riau. 
